medRxiv preprint doi: https://doi.org/10.1101/2020.05.31.20112979; this version posted June 2, 2020. The copyright holder for this preprint

\title{
An open resource for $T$ cell phenotype changes in COVID-19 identifies IL-10-producing regulatory $T$ cells as characteristic of severe cases
}

Julika Neumann ${ }^{1,2^{*}}$, Teresa Prezzemolo ${ }^{1,2^{*}}$, Lore Vanderbeke ${ }^{2,3 *}$, Carlos P. Roca ${ }^{4 *}$, Margaux Gerbaux $^{2,5}$, Silke Janssens ${ }^{1,2}$, Mathijs Willemsen ${ }^{1,2}$, Oliver Burton ${ }^{4}$, Pierre Van Mol$^{3}$, Yannick

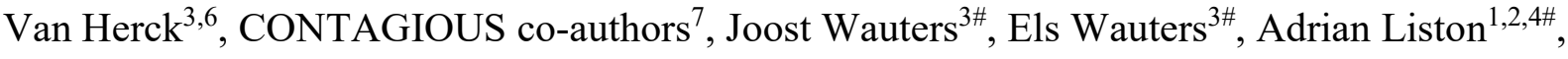
Stephanie Humblet-Baron ${ }^{2 \#}$

${ }^{1}$ VIB Center for Brain and Disease Research, Leuven, Belgium.

${ }^{2}$ KU Leuven - University of Leuven, Department of Microbiology and Immunology, Leuven, Belgium.

${ }^{3}$ UZ Leuven, Leuven, Belgium.

${ }^{4}$ Laboratory of Lymphocyte Signalling and Development, The Babraham Institute, Babraham Research Campus, Cambridge, CB22 3AT United Kingdom.

${ }^{5}$ Pediatric Department, Academic Children Hospital Queen Fabiola, Université Libre de Bruxelles, Brussels, Belgium

${ }^{6}$ VIB Center for Cancer Biology, Leuven, Belgium

${ }^{7}$ CONTAGIOUS co-authors: Francesca Bosisio, Frederik De Smet, Christophe Dooms, Abhishek Garg, Jan Gunst, Greet Hermans, Diether Lambrechts, Natalie Lorent, Kim Martinod, Patrick Matthys, Philippe Meersseman, Johan Neyts, Paul Proost, Jeroen Raes, Sabine Tejpar, Dries Testelmans, Karin Thevissen, Robin Vos, Birgit Weynand, Alexander Wilmer, Carine Wouters, Jonas Yserbyt

*,\# equal contribution

Correspondence to adrian.liston@babraham.ac.uk or stephanie.humbletbaron@kuleuven.be NOTE: This preprint reports new research that has not been certified by peer review and should not be used to guide clinical practice. 
medRxiv preprint doi: https://doi.org/10.1101/2020.05.31.20112979; this version posted June 2,2020 . The copyright holder for this preprint (which was not certified by peer review) is the author/funder, who has granted medRxiv a license to display the preprint in perpetuity. It is made available under a CC-BY-NC 4.0 International license.

\begin{abstract}
The pandemic spread of the novel coronavirus SARS-CoV-2 is due, in part, to the immunological properties of the host-viral interaction. The clinical presentation varies greatly from individual to individual, with asymptomatic carriers, mild to moderate-presenting patients and severely affected patients. Variation in immune response to SARS-CoV-2 may underlie this clinical variation. Using a high dimensional systems immunology platform, we have analyzed the peripheral blood compartment of 6 healthy individuals, 23 mild-to-moderate COVID-19 patients and 20 severe COVID-19 patients. We identify distinct immunological signatures in the peripheral blood of the mild-to-moderate and severe COVID-19 patients, including T cell lymphopenia, more consistent with peripheral hypo- than hyper-immune activation. Unique to the severe COVID-19 cases was a large increase in the proportion of IL-10-secreting regulatory T cells, a lineage known to possess anti-inflammatory properties in the lung. Annotated data is openly available (https://flowrepository.org/experiments/2713) with clinical correlates, as a systems immunology resource for the COVID-19 research community.
\end{abstract}


medRxiv preprint doi: https://doi.org/10.1101/2020.05.31.20112979; this version posted June 2, 2020. The copyright holder for this preprint (which was not certified by peer review) is the author/funder, who has granted medRxiv a license to display the preprint in perpetuity. It is made available under a CC-BY-NC 4.0 International license.

\section{Introduction}

The novel coronavirus SARS-CoV-2 has infected millions of people worldwide, and impacted the society and the global economy in an unprecedented manner. The pandemic spread is due, in part, to the immunological properties of the host-viral interaction. Clinical presentation of SARSCoV-2 infections (COVID-19) varies greatly from individual to individual, with asymptomatic carriers, mild- to- moderate-presenting patients and severely to critically affected patients ${ }^{1 \text {, }}$ $2,3,4,5,6$. This clinical heterogeneity is responsible for the severity of the pandemic, with asymptomatic cases and long latency increasing the R0, and severe pathology at the other end of the clinical spectrum result in high mortality $1,2,3,4,5,6,7,8$. Variation in immune response to SARSCoV-2 may underlie this clinical disparity and unravelling the immunological features associated with progression into severe and life-threatening disease is highly needed in order to guide therapeutic decision making and biomarker discovery.

Immunological investigations during the SARS-CoV-2 pandemic have focused on identifying altered immune responses in COVID-19 patients. Innate immune response is an essential first line defense against viruses, including type I and III interferon (IFN). Recent studies have suggested that SARS-CoV-2 inhibits type I IFN production and signaling ${ }^{9}$, potentially explaining the long pre-symptomatic period and persistent viral load in many patients. Defects in NK cell function may also be present, with reports of higher expression of activation and exhaustion markers on NK cells, and impaired NK cytotoxicity and cytokine production ${ }^{9,10}$, and additional problems with innate immunity are likely to be identified. Other studies suggest a defect in the adaptive immune system. Lymphopenia is widely reported in COVID-19, and the severity of lymphopenia has been correlated with disease severity $10,11,12,13,14,15,16,17,18,19$. Functional defects within $\mathrm{T}$ cells have been reported, with an increased number of non-functional $\mathrm{CD}^{+} \mathrm{T}$ cells and impaired $\mathrm{T}$ cell cytokine production ${ }^{10,11,20}$. In a series of 38 patients, an increase in naïve $\mathrm{CD}^{+}{ }^{+}$was reported in COVID-19 patients, suggestive of impaired activation ${ }^{21}$. This was confirmed in an independent study, but without significant changes between moderate and severe patients ${ }^{22}$, while another study reported no change ${ }^{9}$. Parallel findings were reported in broncho-alveolar lavage fluid of COVID-19 patients, with enrichment of naïve CD4 ${ }^{+} \mathrm{T}$ cells in severely affected patients ${ }^{18}$. Overall, it remains to be determined whether defects in innate or adaptive immunity or a synergistic effect of both underlie the unusually long infectious period of SARS-CoV-2. 
medRxiv preprint doi: https://doi.org/10.1101/2020.05.31.20112979; this version posted June 2, 2020. The copyright holder for this preprint (which was not certified by peer review) is the author/funder, who has granted medRxiv a license to display the preprint in perpetuity. It is made available under a CC-BY-NC 4.0 International license.

Immune analysis is also contributing to an understanding of COVID-19 pathology. Parallels with other respiratory infections, such as influenza ${ }^{23}$, have led to the hypothesis that pathology is immune-mediated rather than due to direct viral induction, and the potential success of immunemodulating therapeutics in small-scale clinical trials provides preliminary support for this model 24,25,26,27. Neutrophils seem to be consistently elevated in severe patients and are associated with poor outcomes ${ }^{10,11,12,13,14,15,16,17,22,28}$. Several studies have identified COVID-19 as a hyperinflammatory status, with a "cytokine storm" of pro-inflammatory cytokines 9,11,13,14,18,29,30,31,32,33. IL-6, in particular, was consistently higher in severely affected patients compared to moderate and milder cases, suggesting it might be associated with disease severity ${ }^{11,13,14,18,30,32,33}$. Inconsistent findings have been reported regarding the changes in myeloid subsets $9,12,34,35$, however, severe COVID-19 patients seem to have an increased number of inflammatory monocytes, producing higher levels of IL-6 and GM-CSF ${ }^{12,35}$. Bronchoalveolar lavage fluid of severe COVID-19 cases also revealed high levels of monocytes and neutrophils as well as a proinflammatory environment ${ }^{18,36}$. Excessive $\mathrm{T}$ cell activation has also been suggested as a possible driver of disease, with increased expression of activation markers (such as HLA-DR, CD38, CD69, CD25, CD44, Ki-67, OX40 and CD137) by CD4 ${ }^{+}$and $\mathrm{CD}^{+} \mathrm{T}$ cells in severe patients $9,11,12,20,21,33$. As with the cause of poor viral clearance, the cause of excessive immune pathology remains unclear.

The ambiguity of the COVID-19 immune profile is based, in part, on the recent origin of the pandemic, but also on the design of COVID-19 clinical trials, many of which have substandard design, lacking suitable controls or data transparency ${ }^{37}$. This probably is especially acute in studies on the phenotypic and functional changes of $\mathrm{T}$ cells, where the limited and sometimes contradictory reports may be attributed to the vagaries of cytometry. Altered gating hierarchy, use of alternative markers, different thresholds for defined expression - each can modify the outcome of analysis ${ }^{38}$. A potential solution is to provide open-access high dimensional data, allowing independent analysis with alternative strategies, while still preserving the rapid publication process required to deal with an evolving pandemic. As part of the CONTAGIOUS consortium, multi-omic approaches are being performed in a systematic and coordinated manner against a longitudinal COVID-19 cohort. Here we provide the first high dimensional flow cytometry analysis for the CONTAGIOUS cohort. The peripheral blood of 6 healthy individuals, 
medRxiv preprint doi: https://doi.org/10.1101/2020.05.31.20112979; this version posted June 2, 2020. The copyright holder for this preprint (which was not certified by peer review) is the author/funder, who has granted medRxiv a license to display the preprint in perpetuity. It is made available under a CC-BY-NC 4.0 International license .

23 mild-to-moderate COVID-19 patients and 20 severe COVID-19 patients, was assessed for changes to the $\mathrm{T}$ cell compartment, and identified a signature of IL-10-producing regulatory $\mathrm{T}$ cells in those patients with severe COVID-19. Annotated data is openly available (https://flowrepository.org/experiments/2713), allowing transparent and evolving data analysis.

\section{Results}

As part of the CONTAGIOUS study into the immunome of COVID-19, patients were recruited through the University Hospital in Leuven, Belgium, beginning 27th March 2020. The dataset was generated on 6 healthy individuals, 23 mild-to-moderate COVID-19 patients (WHO score 34) and 20 severe COVID-19 patients (WHO score 5-7). Demographic data for the patients are summarized in Table 1, with individual data on demographic and clinical values in

\section{Supplementary Resource 1.}

In order to determine the $\mathrm{T}$ cell phenotypes associated with clinical heterogeneity in COVID-19, we stimulated T cells ex vivo and used high parameter flow cytometry covering a comprehensive set of subset markers, activation markers and cytokines. First, we assessed the number of major leukocyte subsets in PBMCs, using key lineage markers (CD3, CD4, CD8, FOXP3, CD14, CD19). Cluster-based flow cytometry analysis, pooling all samples, separated leukocytes into populations that corresponded to $\mathrm{CD}^{+}{ }^{+} \mathrm{T}$ cells, $\mathrm{CD} 8^{+} \mathrm{T}$ cells, $\mathrm{CD} 19^{+} \mathrm{B}$ cells, $\mathrm{CD} 14^{+}$monocytes and $\mathrm{CD}^{-} \mathrm{CD} 8^{-} \mathrm{T}$ cells (Figure 1A,B, Supplementary Figure 1). Traditional gating was used to quantify these populations, and $\mathrm{FOXP}^{+}$regulatory $\mathrm{T}$ cells, in each sample. Despite the marked lymphopenia in COVID-19 patients (Figure 1C), the relative proportion of these leukocyte populations remained unchanged with COVID-19 patients (Figure 1D), other than a trend towards lower CD8 T cell numbers, indicating a non-specific mechanism of leukopenia. Subtle, but significant, differences were observed in the expression of lineage markers, with comparison of pooled mild-moderate and severe COVID-19 patient samples showing a more similar expression pattern than pooled healthy controls (Figure 1E). At the individual level, healthy individuals were largely clustered together, while mild-moderate and severe COVID-19 patients exhibited similar cellular phenotypes (Figure 1F,G). Together, these data indicate only subtle shifts in the balance of blood leukocyte populations with COVID-19, without any discrimination between mild-moderate and severe cases.

We next investigated the activation and polarization of conventional CD4 ${ }^{+} \mathrm{T}$ cells in COVID-19 patients. Using the expression of CD45RA, CCR7, 4-1BB, CD25, CTLA-4, HLA-DR, IFN $\gamma$, IL- 
medRxiv preprint doi: https://doi.org/10.1101/2020.05.31.20112979; this version posted June 2, 2020. The copyright holder for this preprint (which was not certified by peer review) is the author/funder, who has granted medRxiv a license to display the preprint in perpetuity. It is made available under a CC-BY-NC 4.0 International license.

2, IL-4, IL-6, IL-10, IL-17a, PD-1, ROR $\gamma$ t, T-BET and TNF $\alpha$, we clustered the conventional $\mathrm{CD}^{+} \mathrm{T}$ cell population into 15 biologically-distinct subsets: naïve CTLA-4- cells, naïve CTLA$4^{+}$cells, TCM, TCM CTLA-4 $4^{+}$, TCM IL-2 ${ }^{+}$, TEM, TEM Th1 CTLA4 $4^{+}$, TEM Th1 CTLA-4 TEM IL-2 ${ }^{+}$, TEM TNF $\alpha^{+}$, TEM TNF $\alpha^{+}$CTLA- $4^{+}$, TEM PD- ${ }^{\text {high }}$, TEMRA, TEMRA Th1 and TEMRA Th17 (Figure 2A,B, Supplementary Figure 2). Quantification of these subsets across healthy volunteers and COVID-19 patients demonstrated no significant changes, with only a trend towards increased TCM and decreased TEM being present in severe COVID-19 patients, with mild-moderate patients intermediate in number between healthy and severe COVID-19 patients (Figure 2C). Global phenotypic analysis, by contrast, found the cellular phenotype of conventional $\mathrm{CD}^{+} \mathrm{T}$ cells to be more similar between healthy individuals and severe COVID-19 patients (Figure 2D). At an individual level, the cellular phenotypes of healthy, mild-moderate COVID-19 and severe COVID-19 samples were intermingled (Figure 2E,F). This data does not support a peripheral CD4 T cell hyper-activation model of COVID-19.

Using the same approach, we investigated the phenotype of $\mathrm{FOXP}^{+}$regulatory $\mathrm{T}$ cells. Clustering based on expression markers identified 13 regulatory $\mathrm{T}$ cell subsets with biologically distinct characteristics: naïve CTLA-4 $4^{-}$, naïve CTLA-4 $4^{+}$, TEM, TEM CTLA-4 $4^{+}$, TCM, TCM CTLA- $4^{+}$, IL-2 producing CTLA-4 $4^{+}$, IL-10-producing, TNF $\alpha$-producing CTLA-4 ${ }^{+}$, TNF $\alpha-$ producing CTLA-4-, IFN $\gamma$-producing CTLA-4-, IFN $\gamma$-producing CTLA-4 ${ }^{+}$and HLA-DR ${ }^{+}$cells (Figure 3A,B, Supplementary Figure 3). Quantification of these subsets across healthy volunteers and COVID-19 patients demonstrated an increase in TCM CTLA- $4^{+}$regulatory T cells and IL-10-producing regulatory T cells in severe COVID-19 patients, with mild-moderate patients being intermediate (Figure 3C). Manual gating of IL-10-producing regulatory T cells confirmed a 5-fold increase in severe COVID-19 patients only, a significant rise over both healthy individuals and mild-moderate COVID-19 patients (Figure 3D). Cellular phenotypes were largely similar across healthy individuals and COVID-19 patients at both the pool (Figure 3E) and individual (Figure 3F,G) level. While preliminary, the increase in IL-10-producing regulatory $\mathrm{T}$ cells in severe COVID-19 patients is of particular interest, given the role of the murine equivalent in controlling lung inflammation ${ }^{39}$.

Finally, we investigated changes in the $\mathrm{CD}^{+} \mathrm{T}$ cell compartment. 12 subsets of $\mathrm{CD} 8^{+} \mathrm{T}$ cells were identified that correlate to biologically-distinct functions: naïve CTLA-4 ${ }^{-}$, naïve CTLA- $4^{+}$, TEM, TEM Th1, TEM Tc1 IL-2 ${ }^{+}$, TEM Tc1/17, TEM Tc17, TEM IL-2 ${ }^{+}$, TEM TNF ${ }^{+}$, TCM CTLA-4 ${ }^{+}$, TEMRA and TEMRA Tc1 (Figure 4A,B, Supplementary Figure 4). Quantification of individual subsets did not identify any significant changes (Figure 4C), however the highly 
medRxiv preprint doi: https://doi.org/10.1101/2020.05.31.20112979; this version posted June 2, 2020. The copyright holder for this preprint (which was not certified by peer review) is the author/funder, who has granted medRxiv a license to display the preprint in perpetuity. It is made available under a CC-BY-NC 4.0 International license .

inflammatory TEM Tc1/Tc17 population (expressing both IFN $\gamma$ and IL-17) was 13-fold more numerous in COVID-19 patients than in healthy controls, with 27/43 (63\%) COVID-19 patients exhibiting numbers $>2$ standard deviations above the average of healthy individuals

(Supplementary Resource 1). This population did not discriminate between mild-moderate and severe COVID-19 patients. At a global level, the cellular phenotype of $\mathrm{CD} 8^{+} \mathrm{T}$ cells was largely unchanged by COVID-19-status, using both pooled (Figure 4D) and individual (Figure 4E,F) analysis. Together this data suggests an ongoing CD8 T cell response in COVID-19 patients, with expansion of the potent Tc1/Tc17 TEM subset, however the comparative weakness of the response, and its failure to predict disease severity, argue against systemic CD8 T cell responses being a pathogenic driver.

As a resource to the COVID-19 research community we provide in Supplementary Resource 1 the quantification of leukocyte subsets at an individual level, paired with demographic and clinical correlates. We further advocate for independent analysis of this resource, with the raw data available from https://flowrepository.org/experiments/2713.

\section{Discussion}

In this study we present an in-depth investigation of the $\mathrm{T}$ cell compartment of mild to severe COVID-19 patients, using a platform with the capacity to investigate both intracellular transcription factor expression and, in parallel, functional cytokine production on a single cell level. Strikingly, COVID-19 patients that required hospitalization due to their condition harbored a peripheral $\mathrm{T}$ cell landscape that did not differ substantially from the healthy control one regarding the viral response. This is in stark contrast to the normal phenotype arising with viral infections, which specifically trigger Th1/Tc1-driven responses, with increased secretion of IFN $\gamma$ and cytotoxic capacity. This condition has been particularly well studied in the case of influenza which could be considered to date one of the most prevalent respiratory viral infections ${ }^{40,41,42}$. However, patients infected with SARS-CoV-2 do not display this distinct Th1/Tc1 polarization. While the mechanism for this polarization failure remains unknown, a potential explanation lies in the presence of a strong IL-6 environment ${ }^{9,43,44}$. IL-6 is known to affect the Th1/Tc1 response by direct inhibition of IFN $\gamma$ gene expression ${ }^{45,46}$. Accordingly, this observation would support ongoing clinical trials testing the efficacy of tocilizumab in COVID-19 patients.

Our results are in line with recent studies regarding the absence of pro-inflammatory cytokines in the $\mathrm{T}$ cell compartment ${ }^{47}$ or even a decrease of $\mathrm{CD}^{+}{ }^{+}$secreting IFN $\gamma^{11}$. These contrast with data 
medRxiv preprint doi: https://doi.org/10.1101/2020.05.31.20112979; this version posted June 2, 2020. The copyright holder for this preprint (which was not certified by peer review) is the author/funder, who has granted medRxiv a license to display the preprint in perpetuity. It is made available under a CC-BY-NC 4.0 International license.

identifying a Th1 signature in COVID-19 patients; the latter, however, being based on convalescent and non-hospitalized patients ${ }^{48}$. Intriguingly, IFN $\gamma$ levels in COVID-19 patient serum have been reported to be slightly elevated compared to healthy controls ${ }^{9}$. If this is not due to differences in the patient cohort, the lack of a Tc1/Th1 phenotype would suggest a myeloid origin as the IFN $\gamma$ source.

Our study was not able to unravel one of the most prominent features of COVID-19, the prevalent lymphopenia observed in most of the severely affected patients. In our study, both $\mathrm{T}$ and B lymphocyte compartments were affected equally, with a possible predominance for $\mathrm{CD} 8^{+}$ T cells. Importantly, naïve T cells remained present in normal, or elevated, numbers, suggesting that $\mathrm{T}$ cell production/renewal was intact. Interestingly, this lymphocytopenia seems to be systemic, as previous studies in SARS-CoV-1 ${ }^{49}$ and recently in COVID-19 patient autopsy revealed a pan-depletion in all secondary lymphoid organs, including satellite mediastinal lymph nodes with a disrupted architecture ${ }^{50}$ (CONTAGIOUS manuscript in preparation). As massive lymphocyte infiltrates are not reported in lung anatomopathological investigations, lymphodepletion is unlikely to be explained by active recruitment of $\mathrm{T}$ cells to the lung tissues. An alternative cause of this lymphodepletion would be an increased $\mathrm{T}$ cell death, either through direct viral cytolysis or increased apoptosis through activation induced cell death (AICD). While lymphopenia may remain an epiphenomenon, the paucity of $\mathrm{T}$ cells may equally be contributing to disease. This is tentatively supported by results showing HIV positive patients with a slight trend toward poorer COVID-19 outcome ${ }^{51,52,53}$. In addition, patients who received hematopoietic stem cell transplantation (HSCT), which leads to profound T cell lymphopenia ${ }^{54}$, seem to have a worse outcome after SARS-CoV-2 infection, since preliminary data suggest 30\% mortality according to an ongoing EBMT survey ${ }^{55}$. On the other hand, the loss of B cells is less likely to contribute to disease, with patients who are genetically depleted of B cells showing normal outcomes 56,57 .

While the overall $\mathrm{T}$ cell compartment did not display major differences in comparison to healthy controls, there were two particular enriched $\mathrm{T}$ cell subsets in more severely affected patients that could reflect the inflammatory condition present in COVID-19 patients. The inflammatory subset Tc1/Tc17 represents highly activated T cells with high expression of PD-1 and HLA-DR in addition to its ability to secrete both IFN $\gamma$ and IL-17 cytokines. The presence of this population may reflect a deviation from the normal Tc1 anti-viral response caused by the pro-inflammatory IL-6-enriched environment ${ }^{58}$. The contribution of this population to the inflammatory setting is, 
medRxiv preprint doi: https://doi.org/10.1101/2020.05.31.20112979; this version posted June 2, 2020. The copyright holder for this preprint

(which was not certified by peer review) is the author/funder, who has granted medRxiv a license to display the preprint in perpetuity.

It is made available under a CC-BY-NC 4.0 International license.

however, debatable, as the increase in relative number is mitigated by the lymphopenia, and no differences were observed between the mild-moderate and severe COVID-19 patients.

The only peripheral biomarker that did delineate disease severity was the increase in IL-10producing regulatory T cells. Elevated IL-10 has been observed in the serum of COVID-19 patients before ${ }^{11}$, however the cellular source was not elucidated. Production of IL-10 is a hallmark of activated regulatory $\mathrm{T}$ cells that reside in tissues such as the lung. This population, normally rare in healthy individuals, rose up to $\sim 10 \%$ of the regulatory $\mathrm{T}$ cell pool in severe COVID-19 patients. The murine analogue to this population has a potent ability to limit inflammation and tissue damage triggered by microbial and environmental interactions at mucosal surfaces ${ }^{39,59}$. In the case of viral infections of the lung, IL-10 restrains the development of IL-17-producing cells that damage the tissue ${ }^{60,61}$, inhibits the innate inflammatory response to viral particles, and is likely beneficial in reducing the production of cytokines such as IL-6 that have been implicated in COVID-19 morbidity ${ }^{62,63}$. Increase of this suppressive regulatory T cell subset could be a direct response to the progressing lung inflammation in COVID-19 patients, comprising a feedback inhibition circuit to prevent runaway inflammation and death ${ }^{64}$.

Potentially, elevated IL-10 could provide a blood-based biomarker for cases progressing to more severe lung damage. A more intriguing possibility is that individuals with higher IL-10producing regulatory $\mathrm{T}$ cells exhibit defective adaptive immunity. IL- $10^{+}$regulatory $\mathrm{T}$ cells are symptomatic of many unresolved viral infections and are associated with long-term persistence. In respiratory infections, IL-10 potently suppresses anti-viral responses ${ }^{59,65}$ and weakens the immune reaction to superinfection with bacteria ${ }^{66,67}$. Since secondary infection leading to pneumonia is a major cause of death in influenza, and perhaps for some COVID-19 patients as well $^{68,69,70}$, excessive IL-10 production by regulatory $\mathrm{T}$ cells may be a key factor in COVID-19 outcomes. In principle, this truncated adaptive immune response could allow persistent infection and cause an over-reliance on innate responses, driving the pathological state. Under this latter model, early intervention (such as with IL-10 neutralization) could potentially restore appropriate adaptive immunity and quieten the excessively exuberant innate response in the tissue. However key replication, longitudinal and mechanistic studies would be first required, and IL-10 has proven stubbornly refractory to immune modulation in the past ${ }^{71}$.

Key limitations in our study are the study size and the cross-sectional nature. The data presented here rely on a small number of patients without longitudinal follow-up, and lacking asymptomatic patients to screen the full spectrum of the COVID-19 immune signature. Study expansion and follow-up are ongoing to correct these deficits, and identify key components of 
medRxiv preprint doi: https://doi.org/10.1101/2020.05.31.20112979; this version posted June 2, 2020. The copyright holder for this preprint (which was not certified by peer review) is the author/funder, who has granted medRxiv a license to display the preprint in perpetuity. It is made available under a CC-BY-NC 4.0 International license.

the immune system responsible for a better protection against SARS-CoV-2. The other major limitation of the current work is the focus on T cells. With the limited phenotype changes observed here, a more comprehensive study of systemic myeloid cell changes in COVID-19 would be justified. Altogether, our study highlights the absence of a strong anti-viral response against SARS-CoV-2 across mild to severe COVID-19 patients, and the elevated presence of anti-inflammatory IL-10-producing regulatory $\mathrm{T}$ cells in the severely affected patients. This data suggests that a route to normalization of anti-SARS-CoV-2 immunity is critical in the attempt to cure these patients. Finally, with the intent to share and exchange knowledge to accelerate research on this pandemic, our data are available on the following open access repository for further investigation: https://flowrepository.org/experiments/2713.

\section{Methods}

\section{Patient material}

Healthy controls and symptomatic SARS-CoV-2-infected patients (qPCR confirmed) were collected as part of the CONTAGIOUS consortium (manuscript in preparation). Briefly, between March 27th and April 17th 2020, healthy volunteers and adult COVID-19 patients were recruited at COVID-19 hospitalization ward at UZ Leuven (Leuven, Belgium) after informed consent. COVID-19 diagnosis was made based on a positive qRT-PCR on respiratory sample and/or CT imaging compatible with SARS-CoV-2 disease. Patients were classified as mild-moderate (WHO clinical score 3-4) or severe (WHO clinical score 5-7) at point of sampling. All procedures were approved by the UZ Leuven Ethical Committee (protocol study number S63881). Blood samples from healthy controls and patients were stored at $15{ }^{\circ} \mathrm{C}$ for 3-6 hours prior to peripheral blood mononuclear cells (PBMCs) isolation using lymphocyte separation medium (LSM, MP Biomedicals) and freezing in liquid nitrogen. Whole blood count and differential values from the clinical laboratory were obtained concomitantly or within the 24 hours of the blood sample for the flow cytometry analysis.

\section{Flow cytometry}

Frozen PBMCs were thawed, plated and incubated for 4 hours with complete RPMI containing phorbol myristate acetate (PMA $50 \mathrm{ng} / \mathrm{mL})$, ionomycin $(500 \mathrm{ng} / \mathrm{mL})$ and Brefeldin A $(8 \mu \mathrm{g} / \mathrm{mL}$; all Tocris Bioscience) at $37^{\circ} \mathrm{C}$ with $5 \%$ CO2. Cells were then washed twice with PBS (Fisher 
medRxiv preprint doi: https://doi.org/10.1101/2020.05.31.20112979; this version posted June 2, 2020. The copyright holder for this preprint (which was not certified by peer review) is the author/funder, who has granted medRxiv a license to display the preprint in perpetuity. It is made available under a CC-BY-NC 4.0 International license.

Scientific) and stained with live/dead marker (fixable viability dye eFluor780, eBioscience) and fluorochrome-conjugated antibodies against surface markers: anti-CD14 (TuK4), anti-CCR7 (G043H7) (eBioscience); anti-CD3 (REA613) (Miltenyi Biotec); anti-CD4 (SK3), anti-CD8 (SK1), anti-PD1 (EH12.1), anti-CD45RA (HI100) (all from BD Biosciences); anti-CD25 (BC96), anti-HLA-DR (L243), anti-CD40L (24-31), anti-4-1BB (4B4-1), anti-CD19 (HIB19) (all from BioLegend). Cells were fixed with 2\% Formaldehyde (VWR chemicals) and then permeabilized with eBioscience permeabilization buffer according to manufacturer's instructions. Cells were stained overnight at $4^{\circ} \mathrm{C}$ with anti-IFN $\gamma$ (4S.B3), anti-IL-6 (MQ2-13A5), anti-IL17a (N49-653), anti-ROR $\gamma \mathrm{t}$ (Q21-559), anti-IL-2 (MQ1-17H12), anti-IL-10 (JES3-9D7), anti-T-bet (4B10), anti-CTLA-4 (BNI3), anti-GATA3 (L50-823) (all from BD Biosciences); anti-IL-4 (MP4-25D2), anti-TNF $\alpha$ (Mab11), anti-FOXP3 (206D) (all from BioLegend). Data were collected on BD Symphony (BD Biosciences). A maximum of $5 \times 10^{5}$ events were acquired for each sample. tSNE, FlowSOM and heatmap analysis were performed in R (version 3.6.2). Raw .fcs data were compensated and dead cells and debris were gated out prior to file export. The complete set of FCS files used for the COVID-19 cytokine immune phenotyping has been deposited on FlowRepository and annotated in accordance with the MIFlowCyt standard. These files may be downloaded for further analysis from https://flowrepository.org/experiments/2713.

\section{Flow cytometry analysis}

The concatenated dataset was analyzed through successive FlowSOM clustering and tSNE representation after exporting similar event numbers for each sample per condition group and then subsampling equal event numbers per condition. First, lineage markers (CD3, CD4, CD8, FOXP3, CD19, CD14) were used to separate leukocyte subsets. Second, activation markers (41BB, CCR7, CD25, CD45RA, CTLA-4, HLA-DR, IFN $\gamma$, IL-2, IL-4, IL-6, IL-10, IL-17a, PD-1, ROR $\gamma$ t, T-bet, TNF $\alpha$ ) were used to distinguish phenotypic clusters of each leukocyte subset, again using FlowSOM and tSNE. The characteristics of each identified cluster were assessed by means of histograms and heatmaps. Comparisons between groups (healthy, moderate COVID-19 and severe COVID-19) were performed with tests on the cross-entropy distributions of the tSNE representations of each group. In brief, for the original and t-SNE space of each tSNE plot, a probability per data point was calculated following the same approach as in the tSNE algorithm. From these point probabilities, the distribution of cross-entropy in the tSNE space relative to the original space was obtained for each group represented in the plot. All pair-wise comparisons 
medRxiv preprint doi: https://doi.org/10.1101/2020.05.31.20112979; this version posted June 2, 2020. The copyright holder for this preprint

(which was not certified by peer review) is the author/funder, who has granted medRxiv a license to display the preprint in perpetuity.

It is made available under a CC-BY-NC 4.0 International license .

between groups were evaluated with Kolmogorov-Smirnov tests on the difference between the cross-entropy distributions. Resulting p-values were corrected with the Holm method.

Dendrograms were obtained from hierarchical clustering, using as distance the KolmogorovSmirnov statistic, that is, the L-infinity distance between the cross-entropy distributions (manuscript in preparation).

\section{Acknowledgements}

This work was supported by the VIB Grand Challenges Program, the KUL C1 program, the FWO Hercules program, the European Union's Horizon 2020 research and innovation programme under grant agreement No 779295 (to A.L.), and the Biotechnology and Biological Sciences Research Council through Institute Strategic Program Grant funding $\mathrm{BBS} / \mathrm{E} / \mathrm{B} / 000 \mathrm{C} 0427$ and BBS/E/B/000C0428, and the Biotechnology and Biological Sciences Research Council Core Capability Grant to the Babraham Institute. MG is supported by a fellowship from the Belgian Kid's Fund. The authors acknowledge the important contributions of the COVID-19 clinical team and Pier-Andrée Penttila and the KUL FACS Core. We are grateful to Per Lungman who kindly provided us with data on COVID-19 disease after HSCT. The manuscript is dedicated to the memory of Michael Wakelam (Babraham Institute). 
medRxiv preprint doi: https://doi.org/10.1101/2020.05.31.20112979; this version posted June 2, 2020. The copyright holder for this preprint (which was not certified by peer review) is the author/funder, who has granted medRxiv a license to display the preprint in perpetuity. It is made available under a CC-BY-NC 4.0 International license.

\section{References}

1. Wu Z, McGoogan JM. Characteristics of and Important Lessons From the Coronavirus Disease 2019 (COVID-19) Outbreak in China. JAMA [Internet]. 2020;323:1239. Available from: https://jamanetwork.com/journals/jama/fullarticle/2762130

2. Richardson S, Hirsch JS, Narasimhan M, Crawford JM, McGinn T, Davidson KW, et al. Presenting Characteristics, Comorbidities, and Outcomes Among 5700 Patients Hospitalized With COVID-19 in the New York City Area. JAMA [Internet]. 2020; Available from: https://jamanetwork.com/journals/jama/fullarticle/2765184

3. Guan W, Ni Z, Hu Y, Liang W, Ou C, He J, et al. Clinical Characteristics of Coronavirus Disease 2019 in China. N Engl J Med [Internet]. 2020;382:1708-20. Available from: http://www.nejm.org/doi/10.1056/NEJMoa2002032

4. Grasselli G, Zangrillo A, Zanella A, Antonelli M, Cabrini L, Castelli A, et al. Baseline Characteristics and Outcomes of 1591 Patients Infected With SARS-CoV-2 Admitted to ICUs of the Lombardy Region, Italy. JAMA [Internet]. 2020;323:1574. Available from: https://jamanetwork.com/journals/jama/fullarticle/2764365

5. Mizumoto K, Kagaya K, Zarebski A, Chowell G. Estimating the asymptomatic proportion of coronavirus disease 2019 (COVID-19) cases on board the Diamond Princess cruise ship, Yokohama, Japan, 2020. Eurosurveillance [Internet]. 2020;25. Available from: https://www.eurosurveillance.org/content/10.2807/1560-7917.ES.2020.25.10.2000180

6. Sutton D, Fuchs K, D'Alton M, Goffman D. Universal Screening for SARS-CoV-2 in Women Admitted for Delivery. N Engl J Med [Internet]. 2020;NEJMc2009316. Available from: http://www.nejm.org/doi/10.1056/NEJMc2009316

7. Liu Y, Gayle AA, Wilder-Smith A, Rocklöv J. The reproductive number of COVID-19 is higher compared to SARS coronavirus. J Travel Med [Internet]. 2020;27. Available from: https://academic.oup.com/jtm/article/doi/10.1093/jtm/taaa021/5735319

8. Li Q, Guan X, Wu P, Wang X, Zhou L, Tong Y, et al. Early Transmission Dynamics in Wuhan, China, of Novel Coronavirus-Infected Pneumonia. N Engl J Med [Internet]. 2020;382:1199-207. Available from: http://www.nejm.org/doi/10.1056/NEJMoa2001316

9. Hadjadj J, Yatim N, Barnabei L, Corneau A, Breillat P, Carlier N, et al. Impaired type I interferon activity and exacerbated inflammatory responses in severe Covid-19 patients. 
medRxiv preprint doi: https://doi.org/10.1101/2020.05.31.20112979; this version posted June 2, 2020. The copyright holder for this preprint (which was not certified by peer review) is the author/funder, who has granted medRxiv a license to display the preprint in perpetuity. It is made available under a CC-BY-NC 4.0 International license.

medRxiv. 2020;2020.04.19.20068015.

https://www.medrxiv.org/content/10.1101/2020.04.19.20068015v1

10. Zheng M, Gao Y, Wang G, Song G, Liu S, Sun D, et al. Functional exhaustion of antiviral lymphocytes in COVID-19 patients. Cell Mol Immunol [Internet]. 2020;17:533-5.

Available from: http://www.nature.com/articles/s41423-020-0402-2

11. Chen G, Wu D, Guo W, Cao Y, Huang D, Wang H, et al. Clinical and immunological features of severe and moderate coronavirus disease 2019. J Clin Invest [Internet]. 2020;130:2620-9. Available from: https://www.jci.org/articles/view/137244

12. Zhou Y, Fu B, Zheng X, Wang D, Zhao C, Qi Y, et al. Pathogenic T cells and inflammatory monocytes incite inflammatory storm in severe COVID-19 patients. Natl Sci Rev [Internet]. 2020; Available from: https://academic.oup.com/nsr/advance$\underline{\text { article/doi/10.1093/nsr/nwaa041/5804736 }}$

13. Diao B, Wang C, Tan Y, Chen X, Liu Y, Ning L, et al. Reduction and Functional Exhaustion of T Cells in Patients With Coronavirus Disease 2019 (COVID-19). Front Immunol [Internet]. 2020;11. Available from: https://www.frontiersin.org/article/10.3389/fimmu.2020.00827/full

14. Liu J, Li S, Liu J, Liang B, Wang X, Wang H, et al. Longitudinal characteristics of lymphocyte responses and cytokine profiles in the peripheral blood of SARS-CoV-2 infected patients. EBioMedicine [Internet]. 2020;55:102763. Available from: https://linkinghub.elsevier.com/retrieve/pii/S2352396420301389

15. Wang F, Nie J, Wang H, Zhao Q, Xiong Y, Deng L, et al. Characteristics of Peripheral Lymphocyte Subset Alteration in COVID-19 Pneumonia. J Infect Dis [Internet]. 2020;221:1762-9. Available from:

\section{https://academic.oup.com/jid/article/221/11/1762/5813618}

16. Wan S, Yi Q, Fan S, Lv J, Zhang X, Guo L, et al. Characteristics of lymphocyte subsets and cytokines in peripheral blood of 123 hospitalized patients with 2019 novel coronavirus pneumonia (NCP). medRxiv. 2020; 2020.02.10.20021832. Available from: https://www.medrxiv.org/content/10.1101/2020.02.10.20021832v1

17. XU B, FAN C, WANG A, ZOU Y, YU Y, HE C, et al. Suppressed T cell-mediated immunity in patients with COVID-19: A clinical retrospective study in Wuhan, China. J 
medRxiv preprint doi: https://doi.org/10.1101/2020.05.31.20112979; this version posted June 2, 2020. The copyright holder for this preprint (which was not certified by peer review) is the author/funder, who has granted medRxiv a license to display the preprint in perpetuity. It is made available under a CC-BY-NC 4.0 International license .

Infect [Internet]. 2020; Available from:

https://linkinghub.elsevier.com/retrieve/pii/S0163445320302231

18. Bost P, Giladi A, Liu Y, Bendjelal Y, Xu G, David E, et al. Host-viral infection maps reveal signatures of severe COVID-19 patients. Cell [Internet]. 2020; Available from: https://linkinghub.elsevier.com/retrieve/pii/S0092867420305687

19. Liu R, Wang Y, Li J, Han H, Xia Z, Liu F, et al. Decreased T cell populations contribute to the increased severity of COVID-19. Clin Chim Acta [Internet]. 2020;508:110-4. Available from: https://linkinghub.elsevier.com/retrieve/pii/S0009898120302163

20. Zheng H-Y, Zhang M, Yang C-X, Zhang N, Wang X-C, Yang X-P, et al. Elevated exhaustion levels and reduced functional diversity of $\mathrm{T}$ cells in peripheral blood may predict severe progression in COVID-19 patients. Cell Mol Immunol [Internet]. 2020;17:541-3. Available from: http://www.nature.com/articles/s41423-020-0401-3

21. Yang X, Dai T, Zhou X, Qian H, Guo R, Lei L, et al. Analysis of adaptive immune cell populations and phenotypes in the patients infected by SARS-CoV-2. medRxiv. 2020; 2020.03.23.20040675. Available from: https://www.medrxiv.org/content/10.1101/2020.03.23.20040675v2

22. Qin C, Zhou L, Hu Z, Zhang S, Yang S, Tao Y, et al. Dysregulation of Immune Response in Patients With Coronavirus 2019 (COVID-19) in Wuhan, China. Clin Infect Dis [Internet]. 2020; Available from: https://academic.oup.com/cid/advancearticle/doi/10.1093/cid/ciaa248/5803306

23. Herold S, Becker C, Ridge KM, Budinger GRS. Influenza virus-induced lung injury: pathogenesis and implications for treatment. Eur Respir J [Internet]. 2015;45:1463-78. Available from: http://erj.ersjournals.com/lookup/doi/10.1183/09031936.00186214

24. Cavalli G, De Luca G, Campochiaro C, Della-Torre E, Ripa M, Canetti D, et al. Interleukin-1 blockade with high-dose anakinra in patients with COVID-19, acute respiratory distress syndrome, and hyperinflammation: a retrospective cohort study. Lancet Rheumatol [Internet]. 2020; Available from:

https://linkinghub.elsevier.com/retrieve/pii/S2665991320301272

25. Toniati P, Piva S, Cattalini M, Garrafa E, Regola F, Castelli F, et al. Tocilizumab for the treatment of severe COVID-19 pneumonia with hyperinflammatory syndrome and acute 
medRxiv preprint doi: https://doi.org/10.1101/2020.05.31.20112979; this version posted June 2, 2020. The copyright holder for this preprint (which was not certified by peer review) is the author/funder, who has granted medRxiv a license to display the preprint in perpetuity. It is made available under a CC-BY-NC 4.0 International license .

respiratory failure: A single center study of 100 patients in Brescia, Italy. Autoimmun Rev [Internet]. 2020;102568. Available from:

https://linkinghub.elsevier.com/retrieve/pii/S1568997220301300

26. Xu X, Han M, Li T, Sun W, Wang D, Fu B, et al. Effective treatment of severe COVID19 patients with tocilizumab. Proc Natl Acad Sci [Internet]. 2020;117:10970-5. Available from: http://www.pnas.org/lookup/doi/10.1073/pnas.2005615117

27. Merad M, Martin JC. Pathological inflammation in patients with COVID-19: a key role for monocytes and macrophages. Nat Rev Immunol [Internet]. 2020; Available from: http://www.nature.com/articles/s41577-020-0331-4

28. Chen X, Ling J, Mo P, Zhang Y, Jiang Q, Ma Z, et al. Restoration of leukomonocyte counts is associated with viral clearance in COVID-19 hospitalized patients. medRxiv [Internet]. 2020;2020.03.03.20030437. Available from:

http://medrxiv.org/content/early/2020/03/06/2020.03.03.20030437.abstract

29. Huang C, Wang Y, Li X, Ren L, Zhao J, Hu Y, et al. Clinical features of patients infected with 2019 novel coronavirus in Wuhan, China. Lancet [Internet]. 2020;395:497-506.

Available from: https://linkinghub.elsevier.com/retrieve/pii/S0140673620301835

30. Ruan Q, Yang K, Wang W, Jiang L, Song J. Clinical predictors of mortality due to COVID-19 based on an analysis of data of 150 patients from Wuhan, China. Intensive Care Med [Internet]. 2020;46:846-8. Available from: http://link.springer.com/10.1007/s00134-020-05991-x

31. Yang Y, Shen C, Li J, Yuan J, Wei J, Huang F, et al. Plasma IP-10 and MCP-3 levels are highly associated with disease severity and predict the progression of COVID-19. J Allergy Clin Immunol [Internet]. 2020; Available from:

\section{https://linkinghub.elsevier.com/retrieve/pii/S0091674920305765}

32. Liu T, Zhang J, Yang Y, Zhang L, Ma H, Li Z, et al. The Potential Role of IL-6 in Monitoring Coronavirus Disease 2019. medRxiv. 2020;2020.03.01.20029769v2. Available from: https://www.medrxiv.org/content/10.1101/2020.03.01.20029769v2

33. Biasi S De, Emilia R, Campi V, Meschiari M, Gibellini L. Marked T cell activation, senescence, exhaustion and skewing towards TH17 in patients with Covid-19 pneumonia. Nat Res Rev. 1-32. Available from: https://www.researchsquare.com/article/rs-23957/v1 
medRxiv preprint doi: https://doi.org/10.1101/2020.05.31.20112979; this version posted June 2, 2020. The copyright holder for this preprint (which was not certified by peer review) is the author/funder, who has granted medRxiv a license to display the preprint in perpetuity. It is made available under a CC-BY-NC 4.0 International license .

34. Zheng Y, Huang Z, Yin G, Zhang X, Ye W, Hu Z, et al. Study of the lymphocyte change between COVID-19 and non-COVID-19 pneumonia cases suggesting other factors besides uncontrolled inflammation contributed to multi-organ injury. medRxiv. 2020;2020.02.19.20024885. Available from:

\section{https://www.medrxiv.org/content/10.1101/2020.02.19.20024885v4}

35. Zhang D, Guo R, Lei L, Liu H, Wang Y, Wang Y, et al. COVID-19 infection induces readily detectable morphological and inflammation-related phenotypic changes in peripheral blood monocytes, the severity of which correlate with patient outcome. medRxiv [Internet]. 2020;2020.03.24.20042655. Available from:

http://medrxiv.org/content/early/2020/03/26/2020.03.24.20042655.abstract

36. Liao M, Liu Y, Yuan J, Wen Y, Xu G, Zhao J, et al. Single-cell landscape of bronchoalveolar immune cells in patients with COVID-19. Nat Med [Internet]. 2020; Available from: http://www.nature.com/articles/s41591-020-0901-9

37. Glasziou PP, Sanders S, Hoffmann T. Waste in covid-19 research. BMJ [Internet]. 2020;369:m1847. Available from: http://dx.doi.org/doi:10.1136/bmj.m1847

38. Saeys Y, Van Gassen S, Lambrecht BN. Computational flow cytometry: helping to make sense of high-dimensional immunology data. Nat Rev Immunol [Internet]. 2016;16:44962. Available from: http://www.nature.com/articles/nri.2016.56

39. Rubtsov YP, Rasmussen JP, Chi EY, Fontenot J, Castelli L, Ye X, et al. Regulatory T Cell-Derived Interleukin-10 Limits Inflammation at Environmental Interfaces. Immunity [Internet]. 2008;28:546-58. Available from:

https://linkinghub.elsevier.com/retrieve/pii/S1074761308001131

40. Chen K, Kolls JK. T Cell-Mediated Host Immune Defenses in the Lung. Annu Rev Immunol [Internet]. 2013;31:605-33. Available from:

http://www.annualreviews.org/doi/10.1146/annurev-immunol-032712-100019

41. Zielinski CE, Corti D, Mele F, Pinto D, Lanzavecchia A, Sallusto F. Dissecting the human immunologic memory for pathogens. Immunol Rev [Internet]. 2011;240:40-51. Available from: http://doi.wiley.com/10.1111/j.1600-065X.2010.01000.x

42. Wong S-S, Oshansky CM, Guo X-ZJ, Ralston J, Wood T, Seeds R, et al. Severe Influenza Is Characterized by Prolonged Immune Activation: Results From the SHIVERS Cohort 
medRxiv preprint doi: https://doi.org/10.1101/2020.05.31.20112979; this version posted June 2, 2020. The copyright holder for this preprint (which was not certified by peer review) is the author/funder, who has granted medRxiv a license to display the preprint in perpetuity. It is made available under a CC-BY-NC 4.0 International license .

Study. J Infect Dis [Internet]. 2018;217:245-56. Available from: https://academic.oup.com/jid/article/217/2/245/4588399

43. Chen R, Sang L, Jiang M, Yang Z, Jia N, Fu W, et al. Longitudinal hematologic and immunologic variations associated with the progression of COVID-19 patients in China. $\mathrm{J}$ Allergy Clin Immunol [Internet]. 2020; Available from: https://linkinghub.elsevier.com/retrieve/pii/S0091674920306382

44. Blanco-Melo D, Nilsson-Payant BE, Liu W-C, Uhl S, Hoagland D, Møller R, et al. Imbalanced Host Response to SARS-CoV-2 Drives Development of COVID-19. Cell [Internet]. 2020; Available from:

\section{https://linkinghub.elsevier.com/retrieve/pii/S009286742030489X}

45. Diehl S, Anguita J, Hoffmeyer A, Zapton T, Ihle JN, Fikrig E, et al. Inhibition of Th1 Differentiation by IL-6 Is Mediated by SOCS1. Immunity [Internet]. 2000;13:805-15. Available from: https://linkinghub.elsevier.com/retrieve/pii/S1074761300000789

46. Yang R, Masters AR, Fortner KA, Champagne DP, Yanguas-Casás N, Silberger DJ, et al. IL-6 promotes the differentiation of a subset of naive CD8+ T cells into IL-21-producing B helper CD8+ T cells. J Exp Med [Internet]. 2016;213:2281-91. Available from:

https://rupress.org/jem/article/213/11/2281/54647/IL6-promotes-the-differentiation-of-asubset-of

47. Wilk AJ, Rustagi A, Zhao NQ, Roque J, Martinez-Colon GJ, McKechnie JL, et al. A single-cell atlas of the peripheral immune response to severe COVID-19. medRxiv [Internet]. 2020;2020.04.17.20069930. Available from: https://doi.org/10.1101/2020.04.17.20069930

48. Grifoni A, Weiskopf D, Ramirez SI, Mateus J, Dan JM, Moderbacher CR, et al. Targets of $\mathrm{T}$ cell responses to SARS-CoV-2 coronavirus in humans with COVID-19 disease and unexposed individuals. Cell [Internet]. 2020. Available from: https://linkinghub.elsevier.com/retrieve/pii/S0092867420306103

49. Gu J, Korteweg C. Pathology and Pathogenesis of Severe Acute Respiratory Syndrome. Am J Pathol [Internet]. 2007;170:1136-47. Available from: 
medRxiv preprint doi: https://doi.org/10.1101/2020.05.31.20112979; this version posted June 2, 2020. The copyright holder for this preprint (which was not certified by peer review) is the author/funder, who has granted medRxiv a license to display the preprint in perpetuity. It is made available under a CC-BY-NC 4.0 International license.

50. Feng Z, Diao B, Wang R, Wang G, Wang C, Tan Y, et al. The Novel Severe Acute Respiratory Syndrome Coronavirus 2 (SARS-CoV-2) Directly Decimates Human Spleens and Lymph Nodes. medRxiv. 2020;2:2020.03.27.20045427. https://www.medrxiv.org/content/10.1101/2020.03.27.20045427v1

51. Blanco JL, Ambrosioni J, Garcia F, Martínez E, Soriano A, Mallolas J, et al. COVID-19 in patients with HIV: clinical case series. Lancet HIV [Internet]. 2020;7:e314-6. Available from: https://linkinghub.elsevier.com/retrieve/pii/S2352301820301119

52. Kamen-Tuohy S, Carlucci PM, Zacharioudakis IM, Zervou FN, Rebick G, Klein E, et al. Outcomes among HIV-positive patients hospitalized with COVID-10. medRxiv. 2020;2020.05.07.20094797. Available from: https://www.medrxiv.org/content/10.1101/2020.05.07.20094797v1

53. Härter G, Spinner CD, Roider J, Bickel M, Krznaric I, Grunwald S, et al. COVID-19 in people living with human immunodeficiency virus: a case series of 33 patients. Infection [Internet]. 2020. Available from: http://www.ncbi.nlm.nih.gov/pubmed/32394344

54. Hannon M, Beguin Y, Ehx G, Servais S, Seidel L, Graux C, et al. Immune Recovery after Allogeneic Hematopoietic Stem Cell Transplantation Following Flu-TBI versus TLI-ATG Conditioning. Clin Cancer Res [Internet]. 2015;21:3131-9. Available from: http://clincancerres.aacrjournals.org/cgi/doi/10.1158/1078-0432.CCR-14-3374

55. Ljungman P, Styczynski J, Mikulska M, De la Camara R. Coronavirus Disease Covid-19: Ebmt Recommendations Version 8 - May 18, 2020. 2020;2019:1-9. Available from: https://www.ebmt.org/ebmt/news/coronavirus-disease-covid-19-ebmt-recommendationsupdate-march-23-2020

56. Quinti I, Lougaris V, Milito C, Cinetto F, Pecoraro A, Mezzaroma I, et al. A possible role for B cells in COVID-19? Lesson from patients with agammaglobulinemia. J Allergy Clin Immunol [Internet]. 2020; Available from:

https://linkinghub.elsevier.com/retrieve/pii/S0091674920305571

57. Soresina A, Moratto D, Chiarini M, Paolillo C, Baresi G, Focà E, et al. Two X-linked agammaglobulinemia patients develop pneumonia as COVID-19 manifestation but recover. Eigenmann P, editor. Pediatr Allergy Immunol [Internet]. 2020;pai.13263. Available from: https://onlinelibrary.wiley.com/doi/abs/10.1111/pai.13263 
medRxiv preprint doi: https://doi.org/10.1101/2020.05.31.20112979; this version posted June 2, 2020. The copyright holder for this preprint (which was not certified by peer review) is the author/funder, who has granted medRxiv a license to display the preprint in perpetuity. It is made available under a CC-BY-NC 4.0 International license .

58. Gartlan KH, Markey KA, Varelias A, Bunting MD, Koyama M, Kuns RD, et al. Tc17 cells are a proinflammatory, plastic lineage of pathogenic CD8+ T cells that induce GVHD without antileukemic effects. Blood [Internet]. 2015;126:1609-20. Available from: https://ashpublications.org/blood/article/126/13/1609/105444/Tc17-cells-are-aproinflammatory-plastic-lineage

59. Bedoya F, Cheng G-S, Leibow A, Zakhary N, Weissler K, Garcia V, et al. Viral Antigen Induces Differentiation of Foxp3 + Natural Regulatory T Cells in Influenza VirusInfected Mice. J Immunol [Internet]. 2013;190:6115-25. Available from: http://www.jimmunol.org/lookup/doi/10.4049/jimmunol.1203302

60. Chaudhry A, Samstein RM, Treuting P, Liang Y, Pils MC, Heinrich J-M, et al. Interleukin-10 Signaling in Regulatory T Cells Is Required for Suppression of Th17 CellMediated Inflammation. Immunity [Internet]. 2011;34:566-78. Available from: https://linkinghub.elsevier.com/retrieve/pii/S1074761311001270

61. McKinstry KK, Strutt TM, Buck A, Curtis JD, Dibble JP, Huston G, et al. IL-10 Deficiency Unleashes an Influenza-Specific Th17 Response and Enhances Survival against High-Dose Challenge. J Immunol [Internet]. 2009;182:7353-63. Available from: http://www.jimmunol.org/lookup/doi/10.4049/jimmunol.0900657

62. Chang J, Kunkel SL, Chang C-H. Negative regulation of MyD88-dependent signaling by IL-10 in dendritic cells. Proc Natl Acad Sci [Internet]. 2009;106:18327-32. Available from: http://www.pnas.org/cgi/doi/10.1073/pnas.0905815106

63. Coomes EA, Haghbayan H. Interleukin-6 in COVID-19: A Systematic Review and MetaAnalysis. medRxiv. 2020;2020.03.30.20048058. Available from: https://www.medrxiv.org/content/10.1101/2020.03.30.20048058v1

64. Rojas JM, Avia M, Martín V, Sevilla N. IL-10: A Multifunctional Cytokine in Viral Infections. J Immunol Res [Internet]. 2017;2017:1-14. Available from: https://www.hindawi.com/journals/jir/2017/6104054/

65. Sun K, Torres L, Metzger DW. A Detrimental Effect of Interleukin-10 on Protective Pulmonary Humoral Immunity during Primary Influenza A Virus Infection. J Virol [Internet]. 2010;84:5007-14. Available from: https://jvi.asm.org/content/84/10/5007 
medRxiv preprint doi: https://doi.org/10.1101/2020.05.31.20112979; this version posted June 2, 2020. The copyright holder for this preprint (which was not certified by peer review) is the author/funder, who has granted medRxiv a license to display the preprint in perpetuity. It is made available under a CC-BY-NC 4.0 International license .

66. Barthelemy A, Ivanov S, Fontaine J, Soulard D, Bouabe H, Paget C, et al. Influenza A virus-induced release of interleukin-10 inhibits the anti-microbial activities of invariant natural killer T cells during invasive pneumococcal superinfection. Mucosal Immunol [Internet]. 2017;10:460-9. Available from: http://www.nature.com/articles/mi201649

67. van der Sluijs KF, van Elden LJR, Nijhuis M, Schuurman R, Pater JM, Florquin S, et al. IL-10 Is an Important Mediator of the Enhanced Susceptibility to Pneumococcal Pneumonia after Influenza Infection. J Immunol [Internet]. 2004;172:7603-9. Available from: http://www.jimmunol.org/lookup/doi/10.4049/jimmunol.172.12.7603

68. Cox MJ, Loman N, Bogaert D, O’Grady J. Co-infections: potentially lethal and unexplored in COVID-19. The Lancet Microbe [Internet]. 2020;1:e11. Available from: https://linkinghub.elsevier.com/retrieve/pii/S2666524720300094

69. Morens DM, Taubenberger JK, Fauci AS. Predominant Role of Bacterial Pneumonia as a Cause of Death in Pandemic Influenza: Implications for Pandemic Influenza Preparedness. J Infect Dis [Internet]. 2008;198:962-70. Available from: https://academic.oup.com/jid/article-lookup/doi/10.1086/591708

70. Zhou F, Yu T, Du R, Fan G, Liu Y, Liu Z, et al. Clinical course and risk factors for mortality of adult inpatients with COVID-19 in Wuhan, China: a retrospective cohort study. Lancet [Internet]. 2020;395:1054-62. Available from:

https://linkinghub.elsevier.com/retrieve/pii/S0140673620305663

71. Saxena A, Khosraviani S, Noel S, Mohan D, Donner T, Hamad ARA. Interleukin-10 paradox: A potent immunoregulatory cytokine that has been difficult to harness for immunotherapy. Cytokine [Internet]. 2015;74:27-34. Available from: https://linkinghub.elsevier.com/retrieve/pii/S1043466614005821 
medRxiv preprint doi: https://doi.org/10.1101/2020.05.31.20112979; this version posted June 2,2020 . The copyright holder for this preprint (which was not certified by peer review) is the author/funder, who has granted medRxiv a license to display the preprint in perpetuity.

It is made available under a CC-BY-NC 4.0 International license.

Table 1. Clinical features of the COVID-19 cohort. Median (25-75 percentiles) for key demographic and clinical parameters of patients entered into the study. BMI, body mass index; CRP, C-reactive protein; n/a, not available; WBC, white blood cell count; WHO, World Health Organization.

\begin{tabular}{llll} 
Parameter & Healthy & Mild-moderate COVID-19 & Severe COVID-19 \\
\hline Number of patients & 6 & 23 & 20 \\
Age (years) & $56(40-62)$ & $58(53-69)$ & $64.5(53-69)$ \\
Male:female ratio & $3: 3$ & $10: 13$ & $14: 6$ \\
WHO score & $\mathrm{n} / \mathrm{a}$ & Score 3: 11/ Score 4: 12 & Score 5: 12/ Score 6: 8 \\
BMI & $\mathrm{n} / \mathrm{a}$ & $25.1(22.7-31.7)$ & $29.1(24.4-32.5)$ \\
CRP $(\mathrm{mg} / \mathrm{L})$ & $\mathrm{n} / \mathrm{a}$ & $72.35(27.6-138.9)$ & $141.2(74.75-239.2)$ \\
WBC $\left(10^{3} / \mu \mathrm{L}\right)$ & $\mathrm{n} / \mathrm{a}$ & $6.32(4.07-9.4)$ & $8.42(6.72-10.06)$ \\
Neutrophil count $\left(\mathrm{x} 10^{3} / \mu \mathrm{L}\right)$ & $\mathrm{n} / \mathrm{a}$ & $4.5(2.9-7.1)$ & $6.05(5.23-8.2)$ \\
Lymphocyte count $\left(\mathrm{x} 10^{3} / \mu \mathrm{L}\right)$ & $\mathrm{n} / \mathrm{a}$ & $1.0(0.8-1.7)$ & $0.9(0.625-1.225)$
\end{tabular}


medRxiv preprint doi: https://doi.org/10.1101/2020.05.31.20112979; this version posted June 2, 2020. The copyright holder for this preprint (which was not certified by peer review) is the author/funder, who has granted medRxiv a license to display the preprint in perpetuity. It is made available under a CC-BY-NC 4.0 International license .

\section{Figures}

\section{Figure 1. Peripheral blood leukocyte changes in mild-moderate and severe COVID-19}

patients. PBMCs were isolated from healthy controls $(n=6)$, mild-moderate COVID-19 patients $(n=23)$ and severe COVID-19 patients $(n=20)$, stimulated and assessed through flow cytometry.

(A) tSNE representation of PBMC populations based on the expression of lineage markers: CD3, CD4, CD8, FOXP3, CD19, CD14. FlowSOM clusters were annotated based on (B) expression of lineage markers across each cluster (see also Fig. S1). (C) Clinical lymphocyte counts for mildmoderate and severe COVID-19 patients. (D) Quantification of leukocyte subsets in healthy controls, mild-moderate COVID-19 and severe COVID-19 patients based on manual gating. (E) tSNE representation of PBMC populations based on aforementioned lineage markers for each condition, namely healthy controls, mild-moderate COVID-19 and severe COVID-19 patients. The dendrogram shows the comparative similarity based on the Kolmogorov-Smirnov statistic calculated using the cross-entropy distributions derived from tSNE. (F) tSNE representation of PBMC populations based on aforementioned lineage markers for each condition, namely healthy controls, mild-moderate COVID-19 and severe COVID-19 patients, with each individual represented in a different color. (G) Dendrogram showing the comparative similarity between individuals based on the Kolmogorov-Smirnov statistic calculated using the cross-entropy distributions derived from tSNE. Mean \pm SEM. 
medRxiv preprint doi: https://doi.org/10.1101/2020.05.31.20112979; this version posted June 2, 2020. The copyright holder for this preprint (which was not certified by peer review) is the author/funder, who has granted medRxiv a license to display the preprint in perpetuity.

It is made available under a CC-BY-NC 4.0 International license .

Figure 1

A

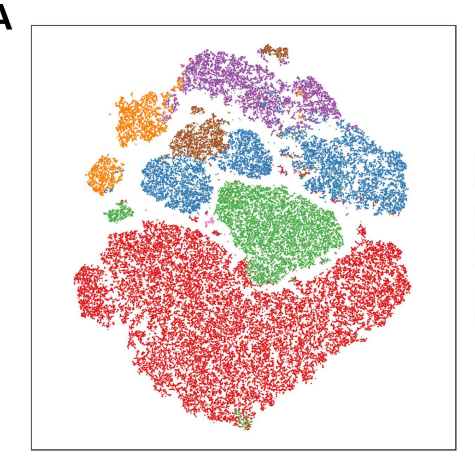

D

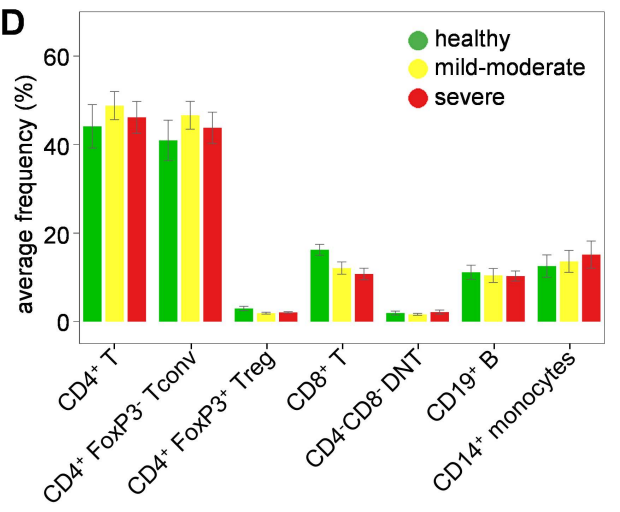

- $\mathrm{CD}^{+} \mathrm{T}$

ICD19+B

- $C D 8^{+} \mathrm{T}$
B

ICD14+ monocytes - CD4-CD8-DNT

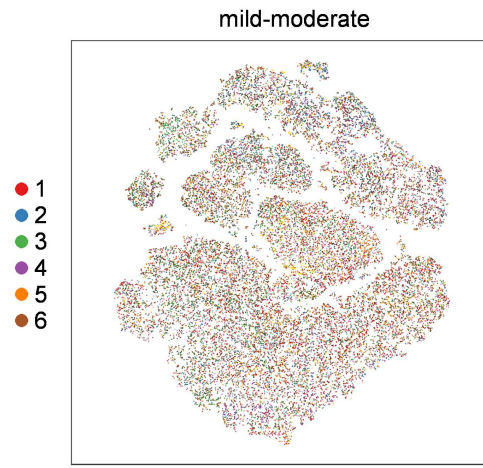

E
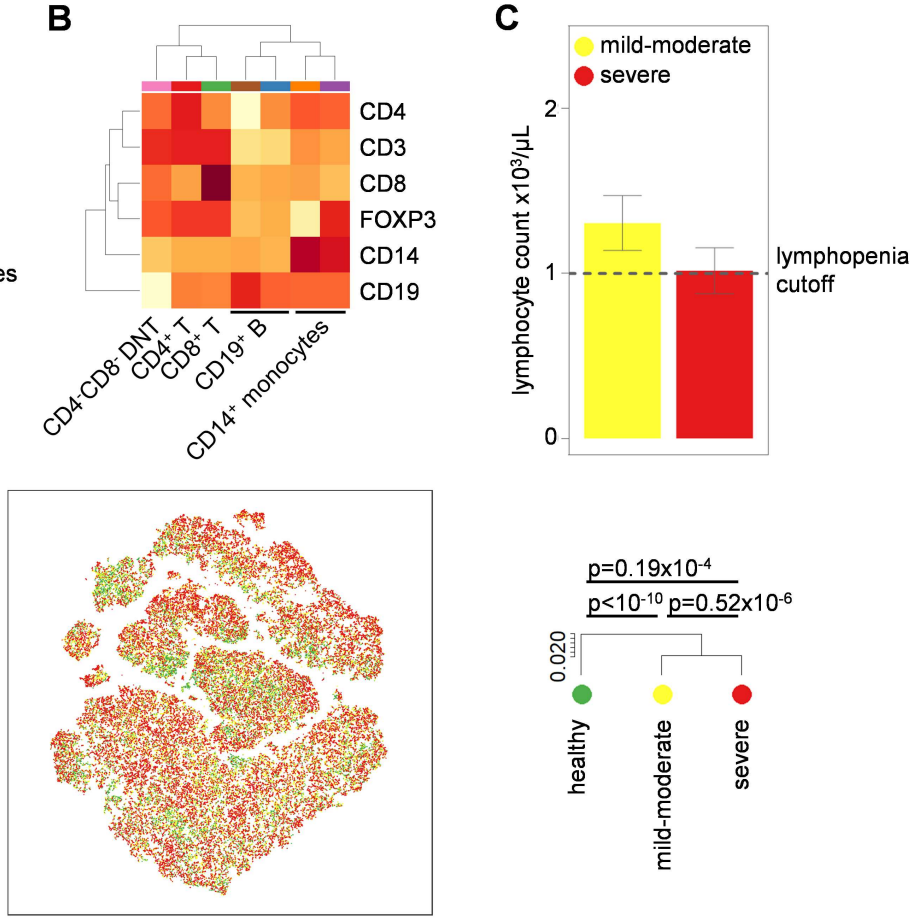

$\mathrm{CD} 4$

$\mathrm{CD} 3$

CD8

FOXP3

CD14 CD19

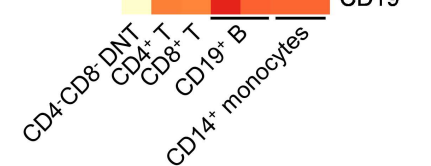

F

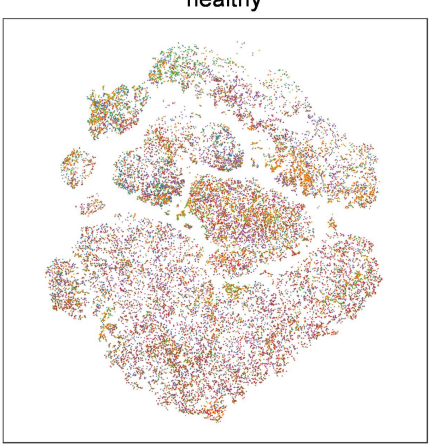

G

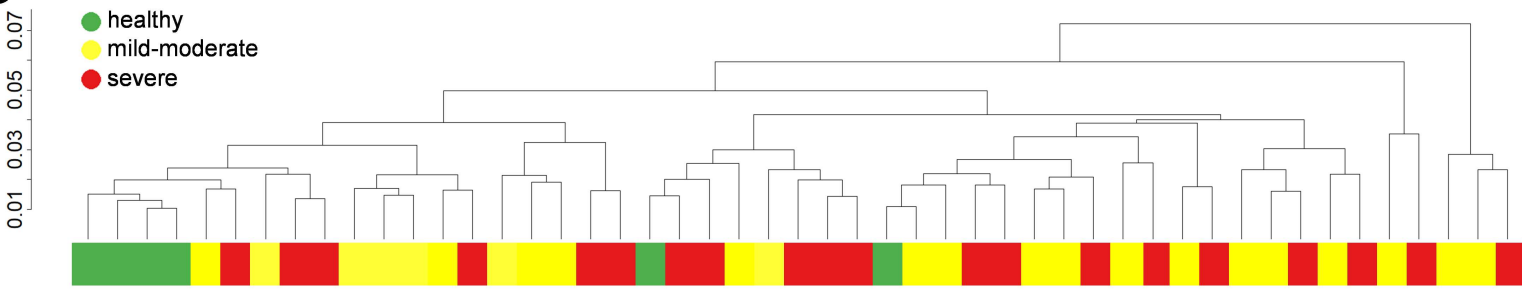


medRxiv preprint doi: https://doi.org/10.1101/2020.05.31.20112979; this version posted June 2, 2020. The copyright holder for this preprint (which was not certified by peer review) is the author/funder, who has granted medRxiv a license to display the preprint in perpetuity. It is made available under a CC-BY-NC 4.0 International license .

Figure 2. Altered conventional T cell phenotypes in COVID-19. PBMCs were isolated from healthy controls $(n=6)$, mild-moderate COVID-19 patients $(n=23)$ and severe COVID-19 patients $(\mathrm{n}=20)$, stimulated and assessed through flow cytometry. $\mathrm{CD}^{+} \mathrm{CD} 14^{-} \mathrm{CD} 4^{+} \mathrm{CD} 8^{-} \mathrm{FOXP} 3^{-}$ conventional T cells were manually gated in FlowJo. (A) tSNE representation of conventional CD4 T cell cluster populations based on the expression of phenotypic markers: CD45RA, CCR7, 4-1BB, CD25, CTLA-4, HLA-DR, IFN $\gamma$, IL-2, IL-4, IL-6, IL-10, IL-17a, PD-1, ROR $\gamma \mathrm{t}$, T-BET, TNFa. FlowSOM clusters were annotated based on (B) expression of phenotypic markers across each cluster (see also Fig. S2). (C) Quantification of conventional T cell subsets in healthy controls, mild-moderate COVID-19 and severe COVID-19 patients. (D) tSNE representation of PBMC populations based on aforementioned phenotypic markers for each condition, namely healthy controls, mild-moderate COVID-19 and severe COVID-19 patients. The dendrogram shows the comparative similarity based on the Kolmogorov-Smirnov statistic calculated using the cross-entropy distributions derived from tSNE. (E) tSNE representation of PBMC populations based on aforementioned phenotypic markers for each condition, namely healthy controls, mild-moderate COVID-19 and severe COVID-19 patients, with each individual represented in a different color. (F) Dendrogram showing the comparative similarity between individuals based on the Kolmogorov-Smirnov statistic calculated using the cross-entropy distributions derived from tSNE. Mean \pm SEM. 
medRxiv preprint doi: https://doi.org/10.1101/2020.05.31.20112979; this version posted June 2, 2020. The copyright holder for this preprint (which was not certified by peer review) is the author/funder, who has granted medRxiv a license to display the preprint in perpetuity.

It is made available under a CC-BY-NC 4.0 International license .

\section{Figure 2}

A

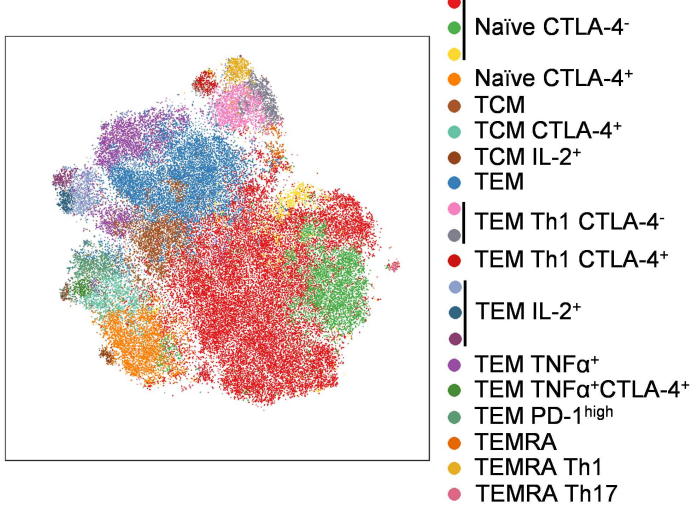

C

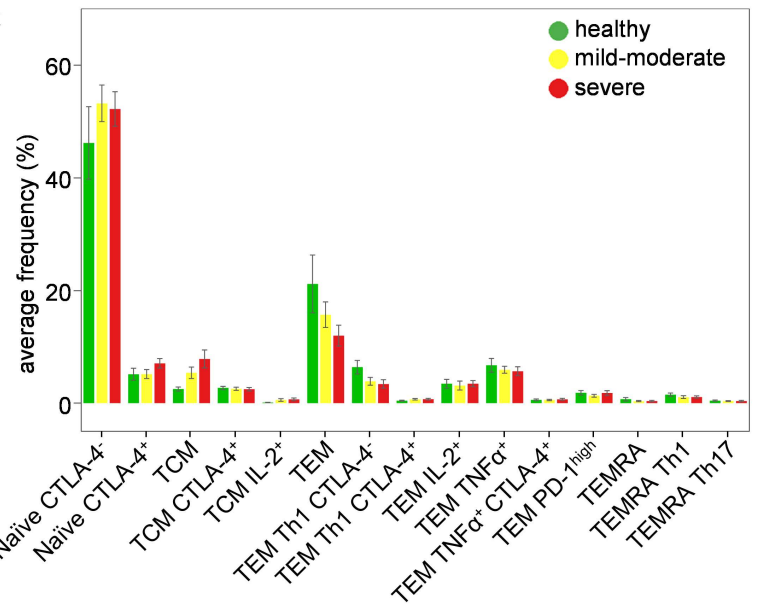

B

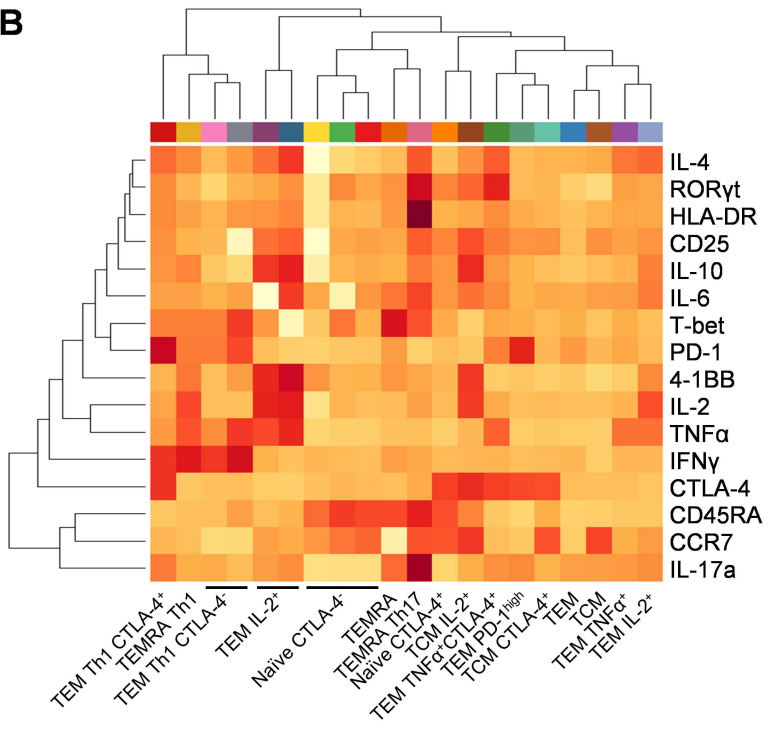

D

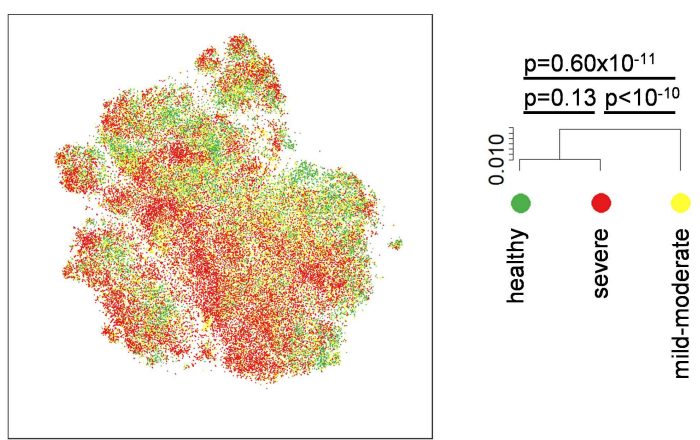
RORyt CD25 -6 PD-1

IFNy CD45RA R7
E

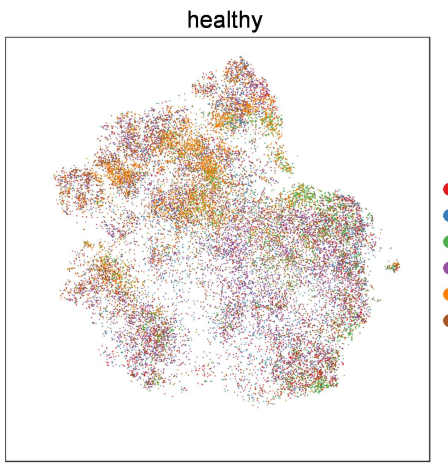

mild-moderate

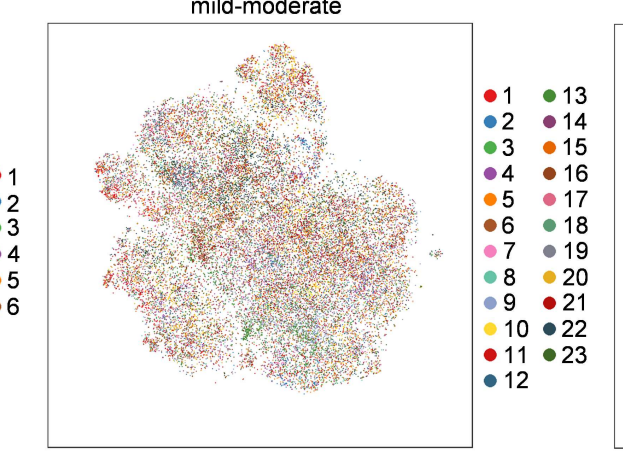

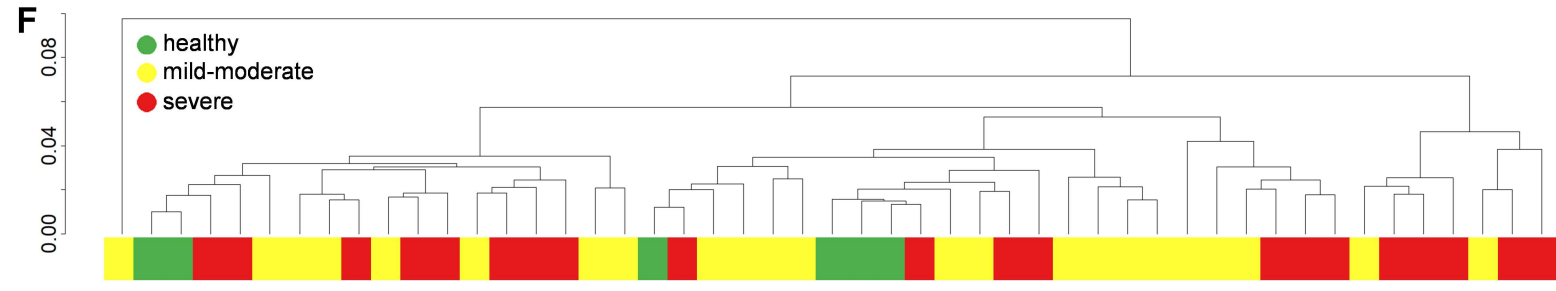


medRxiv preprint doi: https://doi.org/10.1101/2020.05.31.20112979; this version posted June 2, 2020. The copyright holder for this preprint (which was not certified by peer review) is the author/funder, who has granted medRxiv a license to display the preprint in perpetuity. It is made available under a CC-BY-NC 4.0 International license .

Figure 3. Altered regulatory $T$ cell phenotypes in severe and moderate COVID-19. PBMCs were isolated from healthy controls $(n=6)$, mild-moderate COVID-19 patients $(n=23)$ and severe COVID-19 patients $(n=20)$, stimulated and assessed through flow cytometry. $\mathrm{CD}^{+} \mathrm{CD}^{-} 4^{-}$ $\mathrm{CD}^{+} \mathrm{CD} 8-\mathrm{FOXP}^{+}{ }^{+}$regulatory $\mathrm{T}$ cells were manually gated in FlowJo. (A) tSNE representation of regulatory $\mathrm{T}$ cells based on the expression of phenotypic markers: CD45RA, CCR7, 4-1BB, CD25, CTLA-4, HLA-DR, IFN $\gamma$, IL-2, IL-4, IL-6, IL-10, IL-17a, PD-1, ROR $\gamma \mathrm{t}$, T-BET, TNF $\alpha$. FlowSOM clusters were annotated based on (B) expression of phenotypic markers across each cluster (see also Fig. S3). (C) Quantification of regulatory T cell subsets in healthy, mildmoderate COVID-19 and severe COVID-19 patients. (D) Manually gated IL-10 ${ }^{+}$regulatory T cells in healthy, mild-moderate COVID-19 and severe COVID-19 patients. (E) tSNE representation of PBMC populations based on aforementioned phenotypic markers for each condition, namely healthy controls, mild-moderate COVID-19 and severe COVID-19 patients. The dendrogram shows the comparative similarity based on the Kolmogorov-Smirnov statistic calculated using the cross-entropy distributions derived from tSNE. (F) tSNE representation of PBMC populations based on aforementioned phenotypic markers for each condition, namely healthy controls, mild-moderate COVID-19 and severe COVID-19 patients, with each individual represented in a different color. (G) Dendrogram showing the comparative similarity between individuals based on the Kolmogorov-Smirnov statistic calculated using the cross-entropy distributions derived from tSNE. Mean \pm SEM. 
medRxiv preprint doi: https://doi.org/10.1101/2020.05.31.20112979; this version posted June 2, 2020. The copyright holder for this preprint (which was not certified by peer review) is the author/funder, who has granted medRxiv a license to display the preprint in perpetuity.

It is made available under a CC-BY-NC 4.0 International license .

Figure 3

A

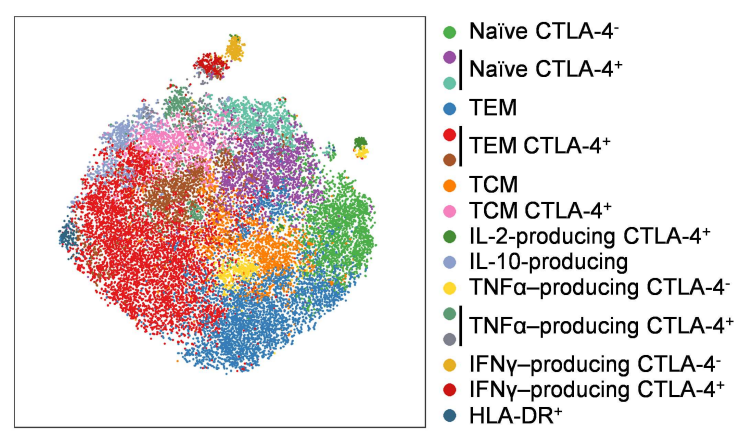

B
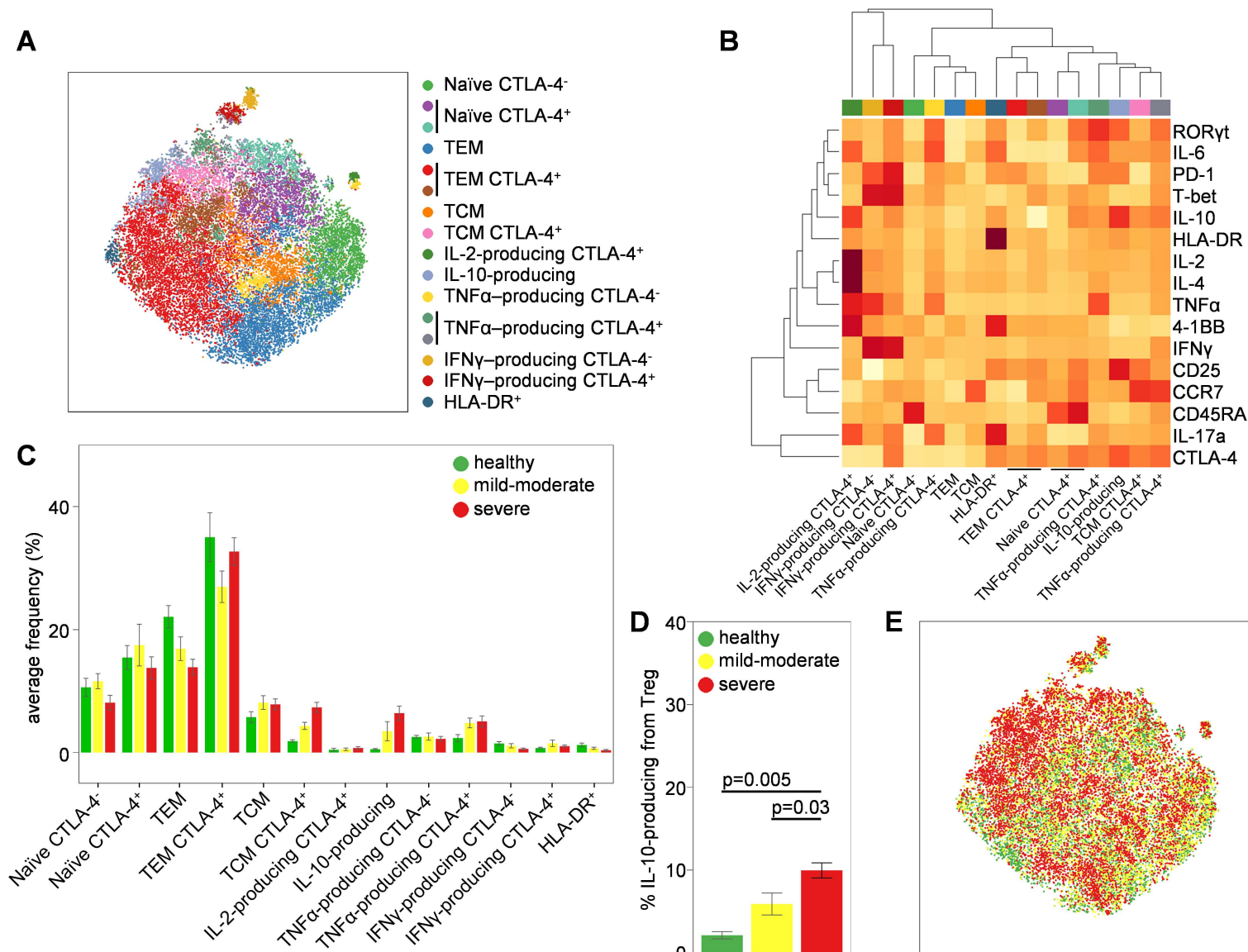

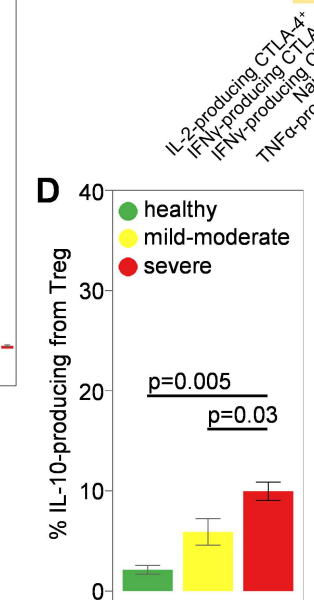

$x$ CTLA-4

E
E

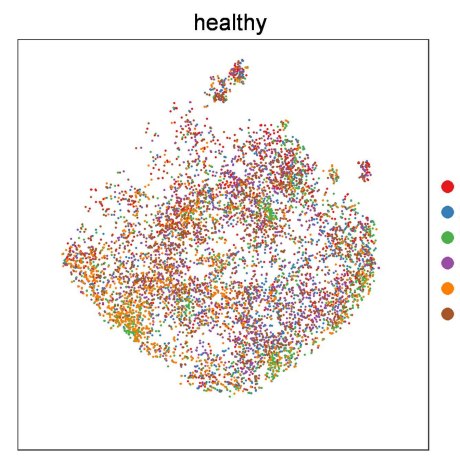

mild-moderate
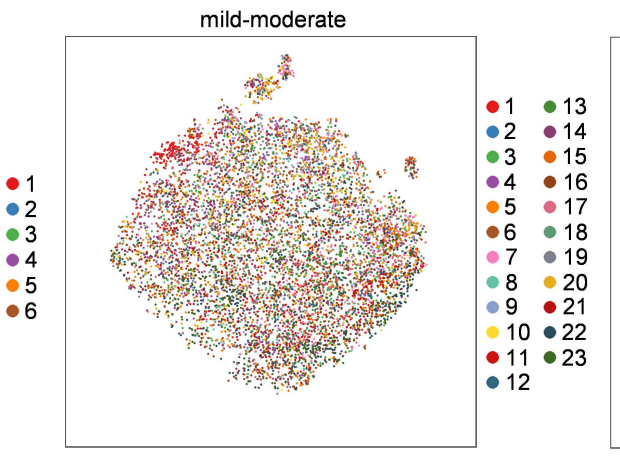

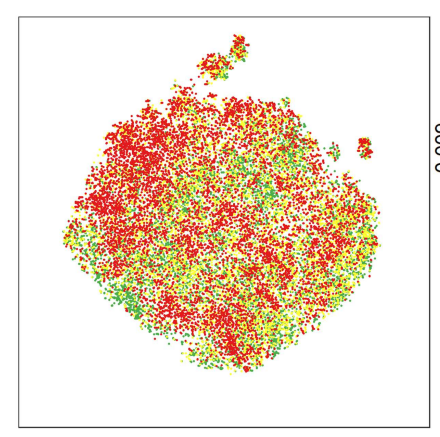

severe

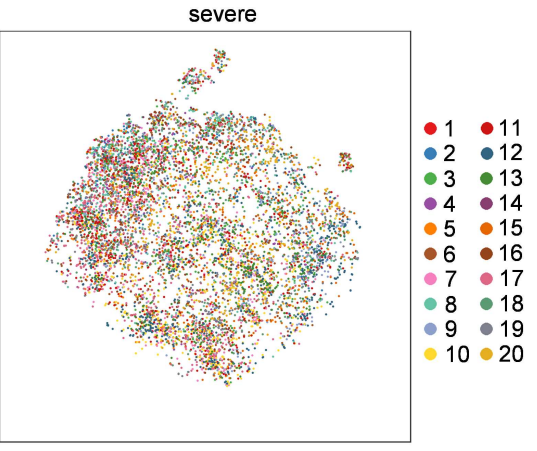

F

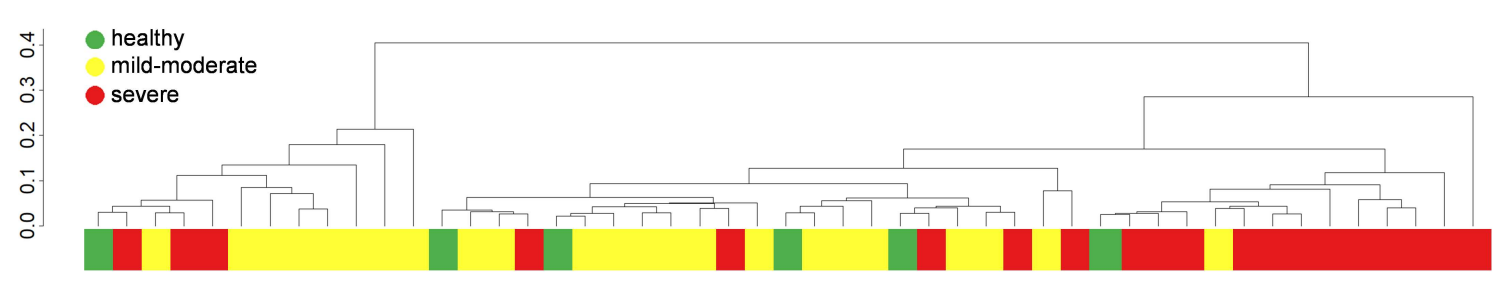


medRxiv preprint doi: https://doi.org/10.1101/2020.05.31.20112979; this version posted June 2, 2020. The copyright holder for this preprint (which was not certified by peer review) is the author/funder, who has granted medRxiv a license to display the preprint in perpetuity. It is made available under a CC-BY-NC 4.0 International license .

Figure 4. Profound activation of CD8+ $\mathrm{T}$ cells in both severe and moderate COVID-19.

PBMCs were isolated from healthy controls $(n=6)$, mild-moderate COVID-19 patients $(n=23)$ and severe COVID-19 patients $(\mathrm{n}=20)$, stimulated and assessed through flow cytometry. $\mathrm{CD}^{+} \mathrm{CD} 14{ }^{-} \mathrm{CD} 4{ }^{-} \mathrm{CD} 8^{+} \mathrm{T}$ cells were manually gated in FlowJo. (A) tSNE representation of CD8 T cell cluster populations based on the expression of phenotypic markers: CD45RA, CCR7, 41BB, CD25, CTLA-4, HLA-DR, IFN $\gamma$, IL-2, IL-4, IL-6, IL-10, IL-17a, PD-1, ROR $\gamma \mathrm{t}$, T-BET, TNFa. FlowSOM clusters were annotated based on (B) expression of phenotypic markers across each cluster (see also Fig. S4). (C) Quantification of CD8 T cell subsets in healthy, moderate COVID-19 patients and severe COVID-19 patients. (D) tSNE representation of PBMC populations based on aforementioned phenotypic markers for each condition, namely healthy controls, mild-moderate COVID-19 and severe COVID-19 patients. The dendrogram shows the comparative similarity based on the Kolmogorov-Smirnov statistic calculated using the crossentropy distributions derived from tSNE. (E) tSNE representation of PBMC populations based on aforementioned phenotypic markers for each condition, namely healthy controls, mildmoderate COVID-19 and severe COVID-19 patients, with each individual represented in a different color. (F) Dendrogram showing the comparative similarity between individuals based on the Kolmogorov-Smirnov statistic calculated using the cross-entropy distributions derived from tSNE. Mean \pm SEM. 
medRxiv preprint doi: https://doi.org/10.1101/2020.05.31.20112979; this version posted June 2, 2020. The copyright holder for this preprint (which was not certified by peer review) is the author/funder, who has granted medRxiv a license to display the preprint in perpetuity.

It is made available under a CC-BY-NC 4.0 International license .

\section{Figure 4}

A

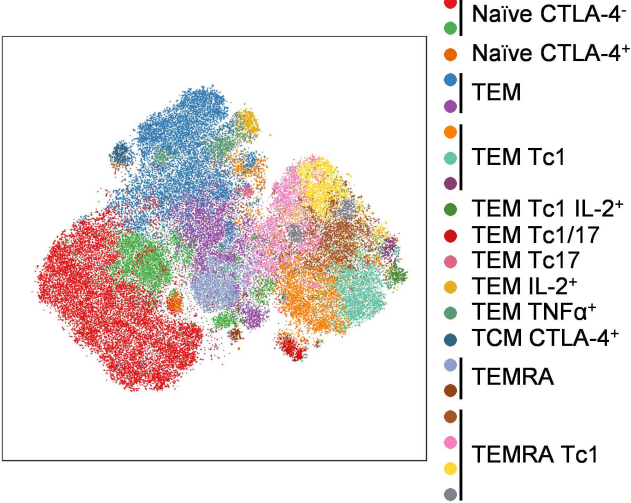

C
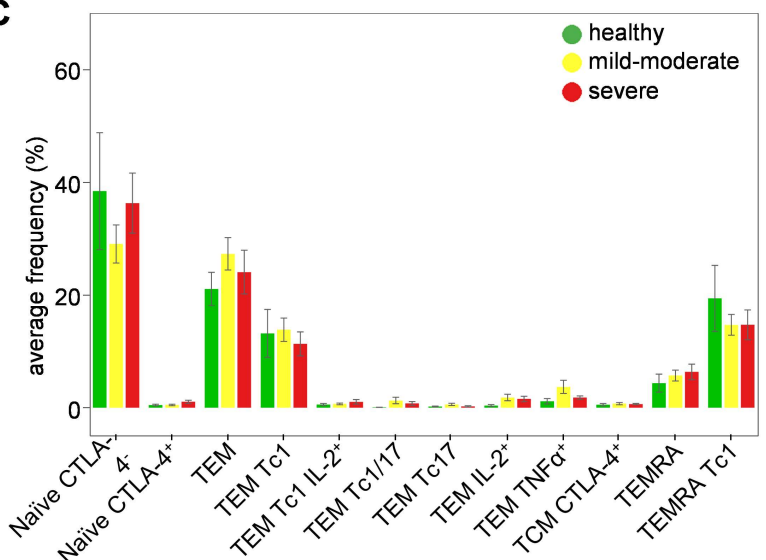

E
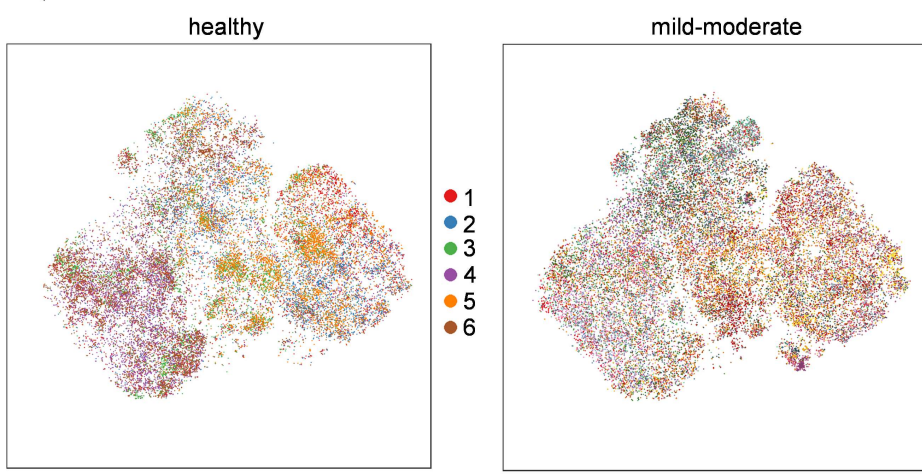

B

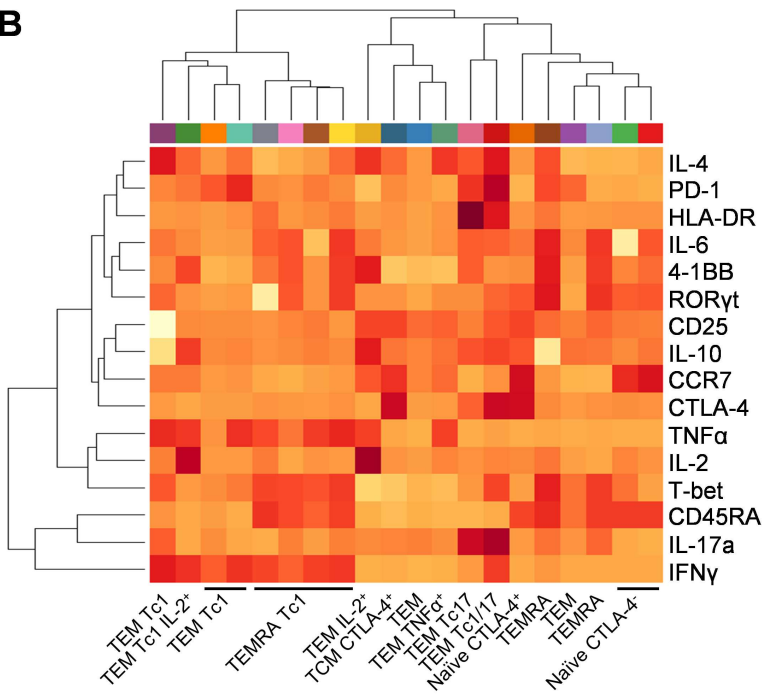

D
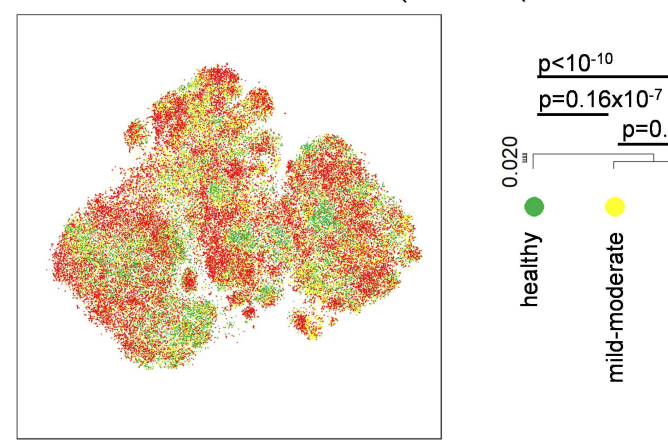

్ㅠㅇㅣ

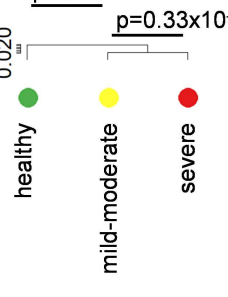

\section{F}

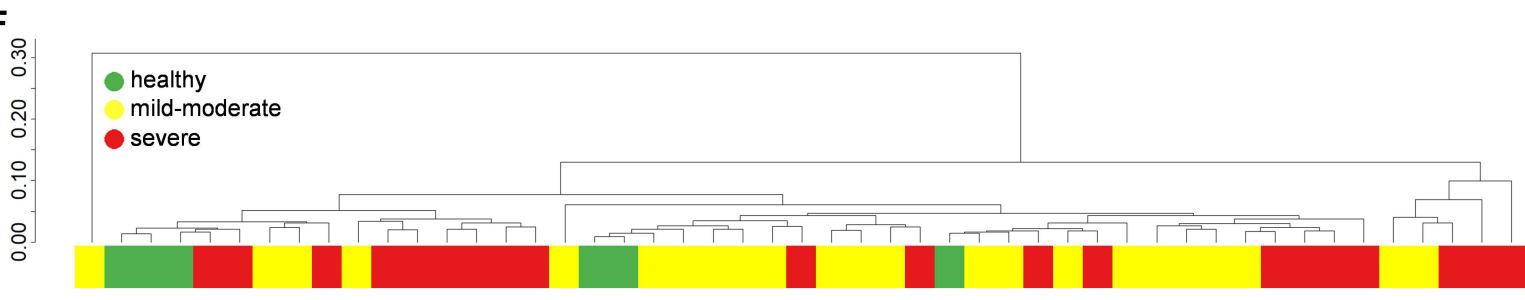

